\title{
CRIME AND PUNISHMENT IN CATULLUS 30
}

S. Thom, Department of Latin, University of Stellenbosch

Alfene immemor atque unanimis false sodalibus, iam te nil miseret, dure, tui dulcis amiculi? iam me prodere, iam non dubitas fallere, perfide? nec facta impia fallacum hominum caelicolis placent, quod tu neglegis ac me miserum deseris in malis. eheu, quid faciant, dic, homines cuiue habeant fidem? certe tute iubebas animam tradere, inique, me inducens in amorem, quasi tuta omnia mi forent. idem nunc retrahis te ac tua dicta omnia factaque uentos irrita ferre ac nebulas aereas sinis.

si tu oblitus es, at Di meminerunt, meminit Fides, quae te ut paeniteat postmodo facti faciet tui.1

\begin{abstract}
"Alfenus, forgetful of faithful friends and false, do you not now pity your dear friend, you hard-hearted one? Do you not hesitate to betray, to deceive me now, you faithless one? The misconduct of deceitful persons do not please the gods above-which you ignore leaving poor me in my predicament; alas, tell me, what should people do, whom should people trust? Truly you indeed used to bid me trust my soul to you while leading me on in love, you unjust one--as if all were safe for me. Now you withdraw from me and you let the winds and the feathery clouds carry off all your words and deeds as meaningless. If you have forgotten this, the Gods indeed remember, Faith remembers, who will soon make you regret your conduct."
\end{abstract}

Scholars have not been able to confirm Alfenus' identity (Syndikus 1984:182 n. 5; Quinn 1970:181; Fedeli 1970:97; Witke 1968:2). The specific nature of his offence has not been clarified either. 2 Not only these two "biographical" uncertainties have influenced response to the poem. Most critics have been uncomfortable with the tone of the poem to such an extent that its validity as a created work of art has been questioned.3

1 I have used the text established by Lee (1990).

2 See Wiseman 1985:123 and Syndikus 1984:182-183 who question details of the offence and Fedeli 1970:98 who accepts betrayal as the basic offence but queries the circumstances. See also Quinn 1970:182: "The details of Catullus' misfortune are not part of the poem's hypothesis, but more than plain assertion of the fact is needed to render plausible the intensity of Catullus' reaction to Alfenus' indifference." Elsewhere Quinn (1970:183) describes the final facti ... tui (v.12) as "too important a part of the poem's hypothesis to be left unexplained". For a different point of view see Witke 1968:8: "Indeed, Catullus makes artistic use of keeping back from his audience the exact nature of his betrayal."

3 See for instance Wiseman 1985:123: "Poem 30 is a very revealing document, but too uncomfortably self-pitying to be an artistic success." See also Vessey 1971:49: "Catullus' attack on Alfenus seems morbid, extreme, almost paranoid" and further "It is the intensity with which they [Catullus' accusations] are expressed that seems abnormal and in a sense repellent and unconvincing." 
This article proposes that the supposedly missing biographical details are unimportant for a proper reading of the poem for the following reasons: (1) Alfenus' historic identity is immaterial to the function of his persona in the poem; 4 and (2) the poem itself provides a sufficiently clear exposition of Alfenus' offence to make sound poetic sense in terms of its own frame of reference. 5

The article further suggests that the poem is an attempt at coming to grips with a given situation, to "replace" the situation, as it were, with a creative poetic alternative. This is especially clear in the careful construction of poetic detail in the poem as well as in the choice of an exceptional metre.

The argument of the poem is the following: Alfenus had persuaded the poet-persona into a relationship or friendship (amicitia). This relationship was based on amor (tute ... me inducens in amorem, vv.7-8). It offered specific guarantees (quasi tuta omnia mi forent, v.8), which implied that mutual trust and commitment (fides) bound the friends together. A relationship based on amicitia and fides presupposes mutual goodwill and support (beneficium). Amor, fides, and beneficium form the basis of amicitia. 6 In this poem the poet-persona faces the problem of friendship which proves not to be based on fides, a friendship which entails no beneficium. Logically such a friendship can be no friendship.7

In C. 30 this complex argument is supported by a relatively simple ring-compositional poetic structure:8

4 See the argument of the poem discussed below.

5 In fact the reader encounters not only an elusive Alfenus but also an insubstantial poet-persona. The entire focus of the poem is on the offence. For a sound analysis of the lack of presence of the former friends, see Vessey 1971:49-50: "For the moment the universe, under the divine powers, contains nothing other than this own agonising predicament" (betrayal by a former friend).

6 See Hellegouarc'h (1963:23-40, 63-90, 142-147, 163-169) for general discussions of fides, amicitia, amor/amare and beneficium. See also Catullus C. 8, C. 64, C. 76 and C. 77 where some aspects of friendship and loyalty are discussed. Especially Catullus C. 64 and C. 76 echo the language of C. 30 closely.

7 See Reitzenstein 1912:16: 'Natürlich verpflichtet das beneficium, die Gunst zu erwidern (gratiam referre); ingratum esse ist schwerer sittliche Vorwurf und berechtigt zur Lösung der Freundschaft; ingratiae amicitiae ist ein Widerspruch in sich selbst." See also Catullus C. 77 where friendship entails no beneficium.

8 Most critics refer to the structure of C. 30 only in passing, since all agree that the poem basically reflects a ring-compositional structure. Not all base their reading of the structure on exactly the same motifs, however. Bardon (1943:14 n.2) bases the ring structure on the motif of remembrance which occurs in immemor, v.1, and oblitus, meminit and meminerunt, vv.1112. Wiseman (1974:65) cursorily proposes a division "into two equal halves of six lines, each beginning with the idea of false friendship and ending with that of fides". Even though this reading is sound as far as the general movement of the poem goes, it is not very helpful in coming to grips with the relationship between separate sections. See Fedeli 1970:99-100 for a more useful division into four sections $(1-3 ; 4-6 ; 7-10 ; 11-12)$. My own analysis differs slightly from that of Fedeli. I read the section on Alfenus' offence (vv.4-10) as a unit instead of focusing on the separate subsections (vv.4-6 and vv.7-10) like Fedeli does. 
A1 Statement of basic problem (vv.1-3):

How Alfenus' forgetfulness, his betrayal of amicitia affects the poet-persona

B Alfenus' offence (vv.4-10):

(1) Broader perspective on Alfenus' crime (vv.4-6)

(2) Personal witness to Alfenus' offence (vv.7-8)

(3) Broader perspective on Alfenus' crime (vv.9-10)

A2 Retribution or amicitia revenged (vv.11-12):

How Alfenus' forgetfulness will affect Alfenus

(1) General: who forgets, who remembers (v.11)

(2) Specific results: who reminds, who remembers (v.12)

Catullus used the metre, the greater asclepiad,9 with its solemn, predominantly spondaic rhythm only in this poem. The poem does not reflect a casual disagreement. It portrays the assessment of a painful situation which has been thought through carefully. 10 Complex thoughts are carefully interwoven, relying on the simple general structure of the poem and slow metre for final impact.11

\section{Statement of the basic problem reflected by the poem}

In the opening section of the poem, Alfenus is addressed with no less than four adjectives with negative connotations (immemor, false, dure, perfide, vv.1-3). Add to this the explicit verbal condemnation te nil miseret ... amiculi (v.2), as well as me prodere ... non dubitas fallere (v.3). The impression created is that Alfenus' guilt is overwhelmingly clear, that there is no need to prove the case in hand. This means that the poem is not concerned with the specific details of Alfenus' offence, but rather with a type of offence and its results.12

\section{Analysis}

The opening vocative Alfene suggests that a communication between two people is taking place, even though only one side of the argument is given.13 This is part of the

See Fedeli 1970:108-109 for the problems posed by this metre for a poet writing in Latin and subsequently, for the effect of this metre for the poem.

10 See C. 109 for Catullus' definition of a special relationship, which in C. 30 proves to have been neither sancta nor a foedus aeternum.

11 Granarolo (1971:365) emphasises the importance of masking the poetic effort demanded by a poem.

12 See also Vessey 1971:51: "Catullus attempts to universalise his own predicament."

13 See the detailed discussions on fides and amicitia in Hellegouarc'b 1963:23-35 and 142-169. He (1963:23-24) also points out that fides in the sense of reciprocal confidence between two people is the basis for amicitia. Fedeli (1970:111) refers to a sacred pact which underlies friendship and which implies retribution when ignored. 
effectiveness of the poem. In this way the poem sustains its unadulterated focus on the crime, not necessarily on the perpetrator of the crime.

\section{Al How Alfenus' forgetfulness, his betrayal of amicitia affects the poet- persona (v.1-3)}

Alfenus' misdeed is initially described as one of "omission". "Not remembering" is the surest sign of complete indifference. No relationship can survive the destructiveness of a lack of interest. Immemor (v.1) is not a word to be used lightly.14 It is further firmly supported by the context within which it operates: unanimis ... sodalibus (v.1). Unanimis makes it clear that this association is not supposed to be based on passing interest, but rather on that rare type of relationship (amicitia) where a bond of trust (fides) exists between two people who like one another (amor), to the mutual advantage of both (beneficium).15

The position of false (v.1) in between unanimis and sodalibus reflects the problem of "friendship" which is basic to this poem.16 Since false comes between unanimis and sodalibus, it denies the very basis on which the special relationship (designated by unanimis) could exist.17 The meaning of false is also affected by its placement. The total enclosure of false by unanimis and sodalibus suggests a close connexion in meaning: false thus operates with reference to friendship, not to some specific action.

The first verse of the poem, suggests a special friendship had existed between unanimis ... sodalibus, that is, between someone (later defined as the poet-persona) and the Alfenuspersona. This verse also hints at Alfenus' crime: On the one hand he has become indifferent to this friendship. On the other hand, his indifference implies that he had never properly understood the meaning or the implications (that friendship could expect beneficium, not impia facta) of the relationship which had come into existence. 18

The statement of the problem posed by the poem becomes more explicit in the second verse. Iom is repeated three times, emphasising the fundamental difference between Alfenus' previous and his present attitude. It supports the idea that a special friendship had previously existed between unanimis ... sodalibus (v.1). The accusation directed against Alfenus is not only that he has become insensitive to his friend's feelings, but especially that he is negligent of the responsibilities towards his friendship. He no longer has empathy with his friend (iam te nil miseret...tui dulcis amiculi?, v.2) which means that the bond of friendship is betrayed. 19

14 Immemor indicates the elevated tone of C. 30 . According to Fedeli $(1970: 102-103)$ in its absolute sense immemor occurs only in "contesti elevari".

15 Cf. Ross 1969:88: 'Alfenus' impious deeds (nec facta impia fallacum hominum caelicolis placent, v.4) are not, in our sense, religious violations, but rather violations of the fides of an amicitia, the central idea of the poem." See also Fedeli 1970:110 who speaks of un patto sacro which exists between real friends.

16 See the exposition of the argument of the poem above.

17 See Reitzenstein 1912:16-19 for a detailed discussion of the meaning and obligations of friendship as well as the consequences implied when these obligations are ignored.

18 See Hellegouarc'h 1963:23-24, who argues that fides in the sense of reciprocal confidence between two people is the basis for friendship (amicitia).

See Putnam 1982:50: "Alfenus, after promising much to the poet, had betrayed and deserted 
Dure dominates this second verse metrically as well as semantically. In this context the harsh $r$ sounds contrast directly with the soft $l$ sounds in dulcis amiculi. Amiculi is no true diminutive. It evokes the same empathy for another human being to which this second verse refers, but which Alfenus' conduct now denies. The contrast between dure and dulcis, emphasised by the alliteration, embodies the change in Alfenus. A dulcis amiculus has become durus, denying the sacred bond which had existed between friends.

The second iam (v.3) links this verse to the previous statement. In the first two verses the accusation against Alfenus is general: sodalibus is plural, the amiculus is not specified, Alfenus is forgetful of and without empathy for $a$ former friend. In verse 3 the accusation is specific. Dulcis amiculi is specified as me, the poet-persona. The significant verb here is (non) dubitas, implying again that Alfenus is not thinking (cf. immemor, v.1) about the consequences of his actions. These actions, however, are critical. Prodere and fallere usually imply that some formal support for a person or principle had existed which has been reneged or violated (Reitzenstein 1912:16, 19). Allegiance implies long term commitment. One would expect an allegiance to be permanent, not unthinkingly forgotten or casually ignored. In verse 1 Alfenus refuses to acknowledge claims made by the friendship which normally exist between unanimis sodalibus. In this verse the crime is the betrayal, as it were in passing, of the bond of friendship which the poet-persona believed to be still intact. Perfide implies that this bond must have existed, must have been acknowledged by Alfenus, whose action now denies this. Alfenus' crime is that he betrays this sacred bond of friendship as if it never had been sacred without thinking (iam non dubitas, v.2) about the implications of his actions.

\section{$B \quad$ Alfenus' offence (vv.4-10)}

In the middle section of the poem (vv.4-10) two ideas are worked out in tandem. On the one hand the nature of Alfenus' misconduct is made clear. On the other hand the bond of friendship between unanimis sodalibus is defined more closely. The crime and its consequences are carefully depicted. Verses 5 and 7-10 give progressively more detailed and damning information about Alfenus' behaviour. Verses 4 and 6 add a broader perspective.

\section{Broader perspective on Alfenus' crime (vv.4-8)}

The first explicit comment on the seriousness of Alfenus' crime appears in verse 4. The poet-persona reminds Alfenus that behaviour has consequences sub specie aeternitatis. 20 The juxtaposition hominum caelicolis (v.4) reinforces the idea of a higher authority who finally evaluates the actions of all human beings. 21 The implication is that Alfenus ${ }^{\circ}$ conduct would be classified as facta impia. Alfenus himself would, further more, be one of the

him." See Catullus C. 76 for a different perspective on a similar situation.

20 Havelock 1938:115: "When friendship grows unhappy, it makes him [Catullus] disclose its inner values; he reveals the fact that for him affection and love are almost a personal religion ... Therefore in friendship he finds moral purpose ..."

21 In v.4 the poet refers to a final higher authority. In this context the explicit nec makes better sense than num as suggested by Goold (1983), for instance. See Fedeli 1970:104 who argues that the archaic nec also fits better than non, the normal negative because of the solemn tone of the poem. 
fallacum hominum. Verse 4 directly confronts Alfenus with the fact that deeds not only have immediate consequences but also evoke much larger "cosmic" reactions. 22

What conduct then causes displeasure even amongst the gods? In verse 5 the poet-persona becomes more specific. Alfenus' crime operates on two levels. In this case the "crime of omission" (quod tu neglegis, v.5) is mentioned first. By implication Alfenus denies ( $t u$ neglegis, v.5) that conduct has the type of repercussions referred to in the previous verse (nec facta impia ... caelicolis placent, v.4). Because of this limited point of view, he feels no responsibility towards his former friend. However, deseris (v.5) is neatly inserted between me miserum and in malis signifying that Alfenus is directly responsible for the poet's pain. 23

Alfenus' crime of commission toward his friend is of the same nature as his crime of omission toward the gods. 24 He turns his back on whatever consequences his friendship might have had for the poet-persona. He denies the natural demands of friendship made on his empathy.25 By this time the indictment against Alfenus is serious: he acknowledges no limitations set by a divine or human code of behaviour.

The result of this attitude is spelled out in the following verse: quid faciant ... homines cuive habeant fidem? Alfenus is called upon (dic) to make "his" code of behaviour clear, if he denies those acknowledged by gods and men. Since the question is rhetorical, it is clear that there is no "other" code of conduct. Alfenus can do what he likes, but he cannot deny the consequences of his action. He attempted to do that by ignoring his duty towards his friendship with the poet-persona. The poem therefore is a solid and lasting reminder of this error of judgement concerning human relationships. At the same time it also refers to Alfenus' unconcern for the larger cosmic consequences of his misconduct. Since the poem will unceasingly indict Alfenus for his crime against a friend it will exact retribution by this reminder continuously. Payment for the more serious crime against friendship, will, by implication, be on a larger scale.

To a certain extent the actions of human beings depend on a frame of reference such as the one guaranteed by the fides of friendship. When this frame of reference is denied, the basis for normal human intercourse is destroyed. If the answer to cuiue habeant fidem? (v.6) is not "a good friend" the alternative is "no one". This state of affairs indeed elicits the cry of complaint eheu!

The point of view of the gods concerning Alfenus' conduct is portrayed in verse 4: nec ... caelicolis placent. The human reaction (uncertainty and insecurity) follows in verse 6: [dic] quid faciant homines cuiue habeant fidem? In verses 7-10 Alfenus' behaviour is discussed against this background (vv.4-6).

22 See Catullus C. 64 for a close parallel in tone and detail to C. 30.

23 Cf. Catullus C. 8 where a similar situation is treated but the focus remains on the victim of the situation. See also C. 63 and C. 64 where miser is used repeatedly. In both cases the protagonists are confronted with a cruel and irrevocable fate.

24 These two aspects of Alfenus' crime are linked by ac (v.5). Since the use of ac is associated with "elevated prose and epic poetry" (Ross 1969:33) it underlines the seriousness and extent of the offence.

25 Hellegouarc'h (1963:25) emphasises not only mutual confidence in each other as concomitant to friendship, but also underlines the necessity of a mutual guarantee of emotional safety for friends. 


\section{Personal witness to Alfenus' offence (vv.7-8)}

Alfenus' crime consists of action taken in the past ( $\mathrm{vv.7-8)}$ as well as continued into the present (vv.9-10). The striking verb concerning action in the past is the imperfect iubebas (v.7). Alfenus' past misdeed was certainly no random accident. It happened repeatedly. To make this even clearer iubebas (v.7) is preceded by the spondaic certe and the explicit tute. 26 The crime is specified when there is no doubt about Alfenus' guilt. He persuaded the poet-persona to put himself at risk (animam tradere, v.7) implying that those guarantees existed (quasi tuta omnia mi forent, v.8) without which the danger of a personal commitment would not have been accepted, without which no friendship could have existed. Animam refers to the whole being of the poet-persona.27 It also echoes the unanimis ... sodalibus of the opening verse of the poem. Here it becomes clear that Alfenus had implied that the safeguards which exist for companions of the soul would exist for the poet-persona. The vocative inique (v.7) separating, as it does, animam tradere from me graphically illustrates that Alfenus' crime threatens the poet-persona's existence as an integrated personality.

The continuous effect of the imperfect iubebas (v.7) is echoed by the present participle inducens (v.8). This supports the idea that the friendship continued for a period of time. Together with animam tradere (v.7), inducens in amorem (v.8) spells out that Alfenus' conduct is a crime against human relationships. The major problem with the transgression is reflected in the word quasi. This implies deliberate deceit on the part of Alfenus. In other words Alfenus' past actions were calculated to persuade the poet-persona to become friends with a man who pretended (by his conduct at least) to offer the emotional safeguards and guarantees which normally go without saying in friendship. Alfenus was aware of the risk involved for the poet-persona: quasi tuta omnia mi forent (v.8) states that quite clearly. The impression is created of a seducer, a man who enjoys being the masculine equivalent of a femme fatale. 28

\section{Broader perspective of Alfenus' crime (vv.9-10)}

The crime against the trustful friend continues in the present: idem nunc retrahis te (v.9). This is only to be expected since the logical consequences of the preceding deceit entail withdrawal at some stage.

Since nunc retrahis te (v.9) follows immediately after quasi tuta omnia mi forent ( $v .8)$ the implicit connexion between these two actions is underlined, i.e., that when the poetpersona no longer hesitated, but put himself at risk in the relationship, Alfenus lost interest. In other words, not the "prey" (relationship) but the "hunt" (mastering the

The familiar diction of tute (v.7) forms a striking contrast to the formal unique (v.7) which echoes immemor, false (v.1), dure (v.2) and perfide (v.3). The first enjambement of the poem also occurs between verses 7-8, reflecting the ease and familiarity of the relationship in the past and implying the strain and restraint of the present.

27 Horace refers to Virgil as his animae dimidium meae (Carm. 1.3.8) implying that friends share the same soul. This is in fact a commonplace also expressed in a proverb such as amicitia plurimonum corporum unus animus (see Otto [1890] 1988:25-26).

28 That the poet-persona should have noticed the absence of true fellow-feeling in a close relationship is immaterial for the argument of the poem. Cf. the apt comment of Wiseman (1985:122) on the Catu!lan approach to life in general: "It was a dangerously vulnerable set of attitudes to take into the corrupt and cynical world of Roman high society." 
situation) was Alfenus' objective. In such a case the individuality of the "prey" is irrelevant, reflecting a most destructive attitude towards a fellow human being. The "irony" of quasi tuta omnia mi forent (v.8) is painfully obvious.29

In verses 9-10 two actions are linked by ac (nunc retrahis te ac tua dicta ..., v.9), as well as two objects (vento ... ac nebulas aereas, v.10). Again the tone evokes an epic seriousness which presupposes that conduct will bear consequences. Alfenus' present action (vv.9b-10) is described in the same type of construction (main verb followed by an accusative and infinitive with an accusative object) as his previous conduct (v.7). The chiasm depending on these parallel constructions encloses and at the same time emphasises the opposition between inducens in amorem (v.8) and nunc retrahis te (v.9).

This description of Alfenus action in the present ( $v$ v.9b-10) is more detailed than that of his past conduct (v.7). Alfenus allows the most insubstantial bodies (ventos ... nebulas aereas, v.9) to undo that which usually is the most concrete embodiment of human activity (dicta omnia factaque, v.9). The deliberate juxtaposition of these (normally incompatible) categories emphasises the ironic similarity between them: in the final analysis human words and deeds can be as tenuous as wind and clouds. However, this reference to insubstantial bodies in the sky acts as an echo of caelicolis (v.4) in the opening line of this section (vv.4-10) on Alfenus' crime. Verse 4 placed human action firmly sub specie aeternitatis, which Alfenus' conduct and especially this final action tried to deny (vv.9b10).

In the opening section of the poem (vv.1-3) Alfenus is described as unanimis false sodalibus (v.1). There he is portrayed as untrue to the ideal of friendship. In the detailed analysis of his deeds (vv.7-10) it is suggested that his crime is more comprehensive. Alfenus namely denies all responsibility for his actions independently of their effect on others.

\section{A2 Retribution, or amicitia revenged (vv.11-12)}

If all responsibility for one's actions is denied, no restraint or higher moral authority is acknowledged. Retribution must therefore remain vague. This does not mean that retribution is suspended, on the contrary. Since the very measure of things is disturbed by such behaviour, retribution is inevitable.

\section{Who forgets, who remembers (v.11)}

If Alfenus chooses to forget (si tu oblitus es, v.11) the cosmic order of things, $D i$ meminerunt, meminit Fides (v.11). Oblitus es (v.11) refers back to the initial description of Alfenus (immemor, v.1). In the opening verse Alfenus denied the bonds which tie human beings to one another. If a general code of human behaviour ( $v v .9 b-10)$ is not acknowledged, specific constraints will not be admitted either. But this code of behaviour exists independently of and with no need for recognition by individuals.

\section{Who reminds whom to remember (v.12)}

The retribution referred to in the final verse, implies, however, that the recognition of such qualities of the friends complement each other, could hardly be imagined. 
a code for human conduct is inevitable: (Fides) ... et ut paeniteat ... facti faciet tui (vv.1112). Faciet (v.12) is the only ring-compositional future tense verb in the poem. It is further supported by postmodo as a firm response to the repeated use of iam initially (vv.2-3). Retribution will come in the sense that Alfenus will have to acknowledge the restraints set for human behaviour: (ut) ... te paeniteat ... facti ... tui (v.12). The words referring to Alfenus' behaviour in future as well as those referring to the conduct of Fides are carefully interwoven. This embodies, as it were, Fides' future impact upon Alfenus. There is no escape from the effects of this action. 30

These two final verses further reflect a chiastic construction. Tu oblitus es (v.11a) and te ... paeniteat ... facti ... tui (v.12) [in the sense of remembering with regret] flank the gods and Fides remembering (v.11b) and Fides reminding Alfenus of his offence unceasingly (v.12). The poem itself is the first step in this process of retribution and punishment. Since Alfenus' crime is initially that of "not remembering" what is due to any human relationship and subsequently denying (in his conduct) that human action have serious and lasting repercussions, the poem will keep reminding him of his error.

\section{Conclusion: The punishment fits the crime}

The poet-persona has tried to come to terms with his dilemma. Instead of trusting to the fides of friendship, the poet-persona will now put his trust into the fides of the poem. With the help of Fides the fides of the poem will replace the (broken) fides of friendship. Together with the poem, Fides will take revenge for broken faith.31

\section{BIBLIOGRAPHY}

Bardon, H. 1943. L'art de la composition chez Catulle. Paris: Les Belles Lettres.

Cornish, F.W. 1968. The poems of Gaius Valerius Catullus. Loeb Classical Library. Cambridge, Massachusetts: Harvard University Press.

30 See Havelock 1938:115 who explains as follows: "When friendship is over, its most poignant memory is the 'benefits forgot', which do nothing to heal the loss, but, as he [Catullus] realised with sure insight, protest forever against it."

31 In some ways the poem could be interpreted as a parallel to $C$. 72, where different types of love are contrasted: the fleeting and superficial feeling contrasted with the permanent and serious one. In C. 30 Alfenus' "friendship" proved to be fleeting and superficial. Just as C. 72 attempts to define the differences between two types of love which appear similar on the surface, C. 30 distinguishes between what claims to be friendship and a true bond of amity. In C. 30 the poet works with two possibilities: either Alfenus had considered himself a friend of the poet-persona and had become untrue to this commitment (vv.1-3). In this case Alfenus bad no idea of what friendship really meant - or, alternatively, Alfenus pretended to feel friendship for the poetpersona in order to gain his confidence and subsequently misused this position of trust (vv.410). In this case Alfenus not only had no idea of what friendship was, but also assumed that the consequences of human conduct were irrelevant. Alfenus was therefore guilty of hybris which implied retribution though not necessarily human punishment. The predominately elevated tone of the poem makes it clear that the poem's final revenge has been to put the crime into the (serious) perspective it deserves. 
Fedeli, P. 1970. Il carme 30 di Catullo. Studia Florentina A. Ronconi sexagenario oblata. Roma: Ateneo.

Granarolo, J. 1971. D'Ennius a Catulle: recherches sur les antécédents romains de la "poesie nouvelle". Paris: Les Belles Lettres.

Goold, G.P. 1983. Carmina. London: Duckworth.

Havelock, E.A. 1938. The lyric genius of Catullus. New York: Russell \& Russell.

Hellegouarc'h, J. 1963. Le vocabulaire latin des relations et des partis politiques sous la république. Paris: Les Belles Lettres.

Lee, G. 1990. The poems of Catullus. Oxford: Clarendon.

Otto, A. [1890] 1988. Die Sprichworter und sprichwortlichen Redensarten der Romer. Reprint. Hildesheim: Olms.

Putnam, M.C.J. 1982. Essays on latin lyric, elegy, and epic. Princeton: Princeton University Press.

Quinn, K. 1970. Catullus: the poems. London: Macmillan.

Reitzenstein, R. 1912. "Zur Sprache der lateinischen Erotik." Sitzungsberichte der Heidelberger Akademie der Wissenschaften 12, 1-36.

Ross, D.O. 1969. Style and tradition in Catullus. Cambridge: Harvard University Press.

Syndikus, H.P. 1984. Catull: eine Interpretation. Darmstadt: Wissenschaftliche Buchgesellschaft.

Vessey, D.W.T.C. 1971. "Thoughts on two poems of Catullus." Latomus 30, 45-55.

Wiseman, T.P. 1974. Cinna the poet and other Roman essays. Leicester: Leicester University Press.

Wiseman, T.P. 1985. Catullus and his world: a reappraisal. Cambridge: Cambridge University Press.

Witke, C. 1968. Enarratio Catulliana Carmina L, XXX, LXV, LXVIII. Mnemosyne Supplement 10. Leiden: Brill. 